\title{
ABDULLAH BIN ABDUL KADIR: HADIJAH RAHMAT'S FOCAL POINT IN MALAY LITERATURE
}

\author{
Mawar Safei \\ mar@ukm.my
}

Malay Literature Programme, Centre for Language Studies, Literature and Malay Culture, Faculty of Social Science and Humanity,

National University Malaysia, Bangi, Selangor, Malaysia.

Tel.: +603-89215288

\begin{abstract}
Abdullah bin Abdul Kadir or Abdullah Munshi is a respected figure who is often associated with his standing as the Father of Modern Malay Literature as compared to Hamzah Fansuri. He has become one of Hadijah Rahmat's focal point in her works; whether in her academic research or in creative works. Among others, this paper focused on the standing of Abdullah Munshi which explains her leaning towards him. This is gleaned through her academic works, for example on what she has deduced from Antara Dua Kota (Between Two Cities: Tracing the works of Munsyi Abdullah in and Singapore, In search of Modernity A Study of Concepts of Literature, Authorship and Notions of Self in Traditional Malay Literature or Mengukir Air di Pesisir Sastera Melayu/ Indonesia dalam Arus Jagat. The same applies in the poetry collection Di Tengah Alam (At the Center of Nature), the drama Munsyi or Kurnia Alam (Gift of Nature) that was crafted by Hadijah Rahmat; the personality of Abdullah Munshi which she attempted to discover. This paper shows the link between the two figures in representing among others the continuity of relationship between Malay literature in Malaysia and Singapore.
\end{abstract}

Keywords: Abdullah bin Abdul Kadir, Abdullah Munshi, Hadijah Rahmat, Malay Literature, Malaysian Literature, Singaporean Literature 


\section{INTRODUCTION}

One of the objectives of this article is to perceive the continuity of Malay literature in Malaysia and Singapore. The development of the literature is strengthened by various methods and also helmed influential minds and graduates either through their works or their management of events that are of a literary orientation. Hadijah Rahmat (Dr. and Associate Professor) is among the many names involved; she is part of the academic team of the Asian Languages and Cultures Academic Group, National Institute of Education (NIE) Nanyang University of Singapore and has been greatly involved in Malay literature.

Hadijah Rahmat has fulfilled her intellectual pursuits as an academic by studying and writing many academic research papers either in articles or in books. She is also involved in creative art as a poet. Examples of her academic works include Peranan dan Perkembangan Sastera Kanak-kanak (The Role and development of Childen's Literature) (2006) which is her dissertation for her first Degree at the National University of Singapore (NUS). In the same vein, her work "In Search of Modernity: A Study of Concepts of Literature, Authorship and Notions of Self in Traditional of Malay Literature" (2001), her dissertation for her Doctorate at the School of Oriental and African Studies, London University. Her other works Sastera dan Manusia Melayu Baru: Kumpulan Esei dan Wawancara (Literature and the New Malay: Collection of Essays and Discourses) (1998c) and Kilat Senja: Sejarah Sosial dan Budaya Kampung-kampung di Singapura (The twilight Lightning; Social and Cultural history of Singapore Villages) (2005a). Her poetry writing has also been prolific with her first collection in Di Tengah Alam (In the Midst of the Universe) (1998a) followed by her second collection which has the nuance of a sequel entitled Kurnia Alam (The gift of the Universe) (2013). And her books on children's poetry are Bunga Kasih Ibu (Mother's Flower of Love ) (2010a), and Burung Kenek Kenek (The Cockatoo Birds) (2010b).

Her strength in both academic and creative discourse is excellently portrayed when she focuses her attention on the eminence of Abdullah Munshi the autobiographic writer and historical recorder of the early Malay society. The name of Abdullah Munshi or Abdullah bin Abdul Kadir (herein after referred to as Abdullah) appears in many of her works. The eminence of this Melaka born personality is highlighted in two of her major works namely in the dramatic play Munsyi and Antara Dua Kota (Between Two Cities: Tracing the works of Abdullah Munshi in Melaka and Singapore) (1999). 
In order to answer some of the queries that are presented in this article, the focus of observation is on the status of Abdullah from the viewpoint of Hadijah Rahmat; and explains her focus in presenting his personality. What aspect of his personality is being unearthed? Another work of Hadijah Rahmat is being referred to namely Mengukir Air di Pesisir Sastera Melayu/Indonesia dalam Arus Jagat (2005b) that comprises five articles that concentrates on the comparison between Abdullah and Hamzah Fansuri. Eventually the writings has endeavoured to show the congruence between the two personalities that represents among other things the synergy of Malay literature in Malaysia and Singapore.

\section{ABOUT ABDULLAH BIN ABDUL KADIR}

The observation by J.T. Thomson in Hikayat Abdullah [sic]on Abdullah bin Abdul Kadir goes as follows:

In terms of features, he is a Tamil from South Hindustan; He is tall, a bit stooped at the front, slender, robust, dark skinned, oval faced, with upturned nose and cross-eyed in one eye. He dresses like most Tamils or Melaka Kelings do; with a Acheh trousers, pulicat sarong, patterned shirt, songkok headgear and leather slippers. He has the spirit and pride of an Arab, the perseverance and dedication of a Hindu but with the language and national fervour of a Malay [sic]

Such was the description of his physical and personal attributes focused on by Hadijah Rahmat. Abdullah bin Kadir was born in Kampung Pali, Melaka in 1796, and was the personality in Malay Studies and political history that was often associated his relationship with the British colonialists as Thomas Stamford Raffles' writer at the age of 14. His expertise in reading and writing in the Malay language was refined through studying under his father who was the writer for William Farquhar (Resident of Melaka 18001818). Abdullah also obtained a deep understanding of the Malay language from two aristrocrats, Datuk Astur and Datuk Sulaiman. It is evident that the influences that enhanced his intellectual development came from his family such as from his two uncles who became writers for the British namely Lebai Ismail and Muhammad Latif. More so, his grandmother, Peri Aci was a wise woman who taught children in reading the al-Quran.

Abdullah bin Abdul Kadir had written extensively. Among his works are Syair Singapura Terbakar (1830), Dawa'il-Kulub (1838), Kisah Pelayaran 
Abdullah ke Kelantan (1839), Cerita Kapal Asap (1843), Cerita darihal Haji Sabar Ali (1851), Syair Kampung Gelam Terbakar (1847), Hikayat Abdullah (1849) dan Kisah Pelayaran Abdullah ke Judah (1854). Abdullah bin Abdul Kadir was thought to be the first local person to learn the printing process, from Walter Henry Medhurst, a printer for London Missionaries Society. His early works such as Syair Singapura Terbakar, Kisah Pelayaran Abdullah dan Hikayat Abdullah were among the earliest books printed. Whereas the first magazine identified as printed was Bustan Ariffin (Hadijah, 1999:64). Based on this historical perspective it would be fair to bestow upon him the title "Bapa Percetakan Melayu" (Father of Malay Printers) (Hadijah 1999: 206; Gallop, 1990:98).

In comparison to Hamzah Fansuri, his postion as the Father of Modern Malay literature (bestowed on him by Cyrill Skinner) has been debated by many local and western personalities. In the context of Hadijah Rahmat's research on his standing, through her quest she tries to ratify him through her works. Nevertheless there is a statement by Hadijah Rahmat that she considers the title inappropriate.

The modernization or renewal process of Malay literature is actually an evolutionary process that is formed by the contribution of various writers and not from the works of only one laureate, as is reflected by this title. Even before Abdullah's time there were some writers who contributed to the redevelopment of Malay literature, such as Hamzah Fansuri, Lauddin, Fakih Saghir and Ahmad Rijaluddin.

\section{THE PORTRAYAL OF ABDULLAH BIN ABDUL KADIR IN ACADEMIC RESEARCH}

Hadijah Rahmat's research on the book Antara Dua Kota: Mengesan Jejakjejak Peninggalan Munsyi Abdullah di Melaka dan Singapura (1999) ${ }^{1}$ accorded her the Singapore Literary Prize in 2000. It presented the heritage left by Abdullah Abdul Kadir in Melaka and Singapore; whether in physical or abstract form. As an example, in chapter four, Abdullah was portrayed as the pioneer of printing process in Melaka, as well Singapore and Indonesia (p. 66).

Abdullah was also famous as a linguistic teacher by practicing the "language barter system". He taught the Malay language while at the same time learnt English, Chinese, Arabic and Hindustani from the military officers and troops whom he met in Melaka or Singapore. The dedication 
of Abdullah in teaching and learning, his appetite for learning was so well illustrated by Hadijah Rahmat in the book. This reflects the objective of the researcher to infuse his spirit among the Singaporean Malay society. According to a brief note by Sumardi Ali, The Chief Executive of MENDAKI about Antara Dua Kota (p.iii), the contribution of Abdullah is not only for literature but also through his somewhat controversial personal thinking within the Malay society at that era. His personal views were sharp, brave and ahead of his time. His deep seated love for knowledge that is illustrated in his works was in line with the aspiration of Singapore to build a knowledge based economy.

Chapter six in the book presents a research topic of Hadijah Rahmat in two of her following academic publications which are discussed here, namely the issue of authorship and notion of self. In the book In Search of Modernity: A Study of Concepts of Literature, Authorship and Notions of Self in Traditional of Malay Literature (2001), by Hadijah Rahmat one chapter, namely chapter eight of Hikayat Abdullah concentrates on him. This personality is being compared to other personalities with their own texts such as Hamzah Fansuri (Asrarul Arifin, Sharabul-Ashiqin dan al-Muntahi), Lauddin (Hikayat Nakhoda Muda), Ahmad Rijaluddin (Hikayat Perintah Negeri Benggala), Fakih Saghir (Surat Keterangan Syeikh Jalaluddin), Raja Ali Haji (Tuhfat al Nafis) dan Mohamed Salleh Perang (Tarikh Datuk Bentara Luar Johor).

This segment is presented again in Mengukir Air di Pesisir Sastera Melayu/ Indonesia dalam Arus Jagat 2005b and is part of a Series of Comparative Literature Studies ${ }^{2}$ that was organized by The South East Asian Literature Council. Hadijah Rahmat was the fifth scholar that presented lectures at three countries namely Malaysia (18 October 2001), Indonesia (23 October 2001) and Brunei Darussalam (27 October 2001).

This segment clearly presents a comparison between Abdullah and the reknown Malay writers mentioned before, especially with his rival, Hamzah Fansuri; there are three concepts used namely the literature concept, the authorship concept and the notion of self concept. This framework is used to trace the modernization that is sculptured by the Malay writers concerned. Hadijah Rahmat is well aware that Abdullah's achievements are seen more as a new found technique (printing) terms and does not deny his intellectual framework. Among some of the western personalities who supported Abdulah's position is Marinus Gerardus Emeis (1949) who assumed that Abdullah was the first Malay journalist to step away from conventional 
writing in folklore type language. Meanwhile, Richard Olaf Winstedt (1940) purports that Abdullah was a literary reformist who pursued realism. This view was agreed upon by Za'ba and in the end Cyrill Skinner crowned him as the father of Modern Malay literature. A number of local writers such as Kassim Ahmad, Mohd. Taib Osman, A. Bakar Hamid, Muhammad Haji Salleh and Yahya Ismail also discussed the standing of Abdullah. Meanwhile another group of writers such as Syed Muhammad Naquib al Attas, Ungku Maimunah Mohd Tahir and Hassan Ahmad expressed an entirely different view. For example, Hassan Ahmad refuted the standing of Abdullah as the pioneer of Modern Malay Literature even though he accepted the renewal of language (to break from tradition) and writing technique (autobiographical) which was introduced by Abdullah.

Hadijah Rahmat (2005: 43-51)) expounded the assumption by Abdullah on writing composition, among which are as follows:

(1) Writing as "carpentry" the writer is a carpenter and the language is the tool. The writer should be knowledgeable in using language in the correct and effective manner.

(2) Writing is a heavy and serious duty.

(3) Writing requires high moral values, language expertise and writing expertise.

(4) To learn from old texts to build expertise in writing.

(5) To have a clear objective namely to bring in welfare and prosperity to the writer and the reader.

(6) There are four functions in writing (especially for the young generation)

(a) To learn from past events

(b) To follow good examples and great characters

(c) To stay away from worldly evils

(d) To use a guideline in learning the Malay language

(7) The writer must have a keen, inquisitive mind, diligent observation and a sense of responsibility.

(8) To regard Allah as the foundation of writing, of guidance and strength.

In regard to the art of writing, Hadijah Rahmat has complied what is gleaned from the works of Abdullah especially on the following aspects:

(1) The consistency of the binary opposition technique.

(2) The autobiographical technique as a motivator for all. 
(3) To make reference to and to value traditional texts (quartrains, poems and metaphors).

The inclination portrayed above gives focus to the intellectual personae of Abdullah and in Hadijah Rahmat's view it should be the catalyst and inspiration to the Malay society in Singapore. This is conceived within Antara Dua Kota (1999:197-200) whereby the there are five themes stated by Abdullah on the matter as follows:

(1) Leadership.

(2) Education.

(3) Language.

(4) The art of writing.

(5) The appreciation of literature or the benefits of reading.

In the same article, Hadijah Rahmat stresses that to regard Abdullah as an exemplary focus as well as to value his actions, as a way for current society to familiarize, learn and well as to gain from history. Its objective is to cover the overall writing knowledge that can become a model or discursive subject by current creative writer; for example to upgrade the quality of writing within the young generation of Singapore.

\section{THE PORTRAYAL OF ABDULLAH BIN ABDUL KADIR IN CREATIVE WORKS}

The collection of poems Di Tengah Alam (1998a) comprises 60 poems that were written from 1977 to 1996 . According to the poet's notes (pp. xi-xiii) this collection records the experience as a student, of being in love, marriage, family, social and national issues. Some of the poems stated Abdullah's name for example in "Setitik Noktah" (p. 21) "Antara Paluan Gong dan Sentuhan Doa" (pp. 30-31), "Istilah"(pp. 32-33). In the poem "Istilah" repeated the threat of Abdullah to society/that has existed for centuries, tied to the words of customs. In the three poems above the poet wishes the reader to always remember the strong reminder by Abdullah on the attitude of the Malays.

In the genre of drama, Hadijah Rahmat Wrote Munsyi (1998b) using references to Hikayat Abdullah, Kisah Pelayaran Abdullah ke Kelantan, Kisah Pelayaran Abdullah ke Judah personal letters as well as related historical writings. Munsyi was staged on 25-26 March 1998 by the Teater Kami group with the cooperation of the National Arts Council of Singapore 
(NAC). Arising from this Hadijah Rahmat also wrote a poem "Bahtera Seni”, which was included in her second collection, Kurnia Alam (2013). ${ }^{3}$

Observe the whole poem which transformed into a song by Zubir Abdullah.

Lahirmu di tengah kota bersejarah

Besarmu di tengah bauran budaya

Meniti tebing berduri, menuju destinasi seni

Mengharung arus deras siasah.

Laluanmu merentas sungai dan lautan

Menyusuri selat, teluk dan negeri

Betapa hebat ombak kalammu

Melanda ngarai dan pantai perjalanan.

Dayung penamu terus gagah

Layar ilmu terkibar megah

Bahtera seni meluncur bangga

Di samudera luas dan indah semesta.

Dua abad berlalu

Tintamu terus mengocak rasa, mencabar minda

Demi lembaran bersemangat baru

Merubah muara kesenian seluruh Nusantara.

Di bawah biru langit budaya

Lingkaran pelangi senja

Seniman menyelam mutiara nurani kewujudan

pelayaran insani mencari diri dan Ilahi

di pelabuhan kehidupan.

Munsyi,

Dayung pena terus gagah

Layar ilmu terkibar megah

Bahtera seni meluncur bangga

Di samudera luas dan indah semesta.

(You were born in a historic city

You were raised within a mixed culture

Crossing a thorny bank, towards the artistic destination

To slide through fast stream of politics.

Your journey crosses rivers and oceans

Passing channels, bays and states 
How strong the flow of your pen

Hitting canyons and the beach of travel.

The oars of you pen stood strong

The sail of knowledge waved proudly

The vessel of arts moved with pride

On the wide ocean and the wonderful world.

Two centuries passes by

Your writing still touches the feelings and challenges the minds

To open up pages of new spirits

To change the estuary of arts in the Malay Archipelago.

Under the blue cultural skies

The circle of evening rainbows

The artist dives to pick up pearls of inner existence

The journey of man to find himself and the Almighty

At the port of existence.

\section{Munshi}

Your writing strives so bravely

Your sail of knowledge proudly waving

Your ship of arts sailing so proudly

On the wide oceans and in wonderful worlds.)

This poem touches upon Abdullah's journey in life including facing up to "a thorny bank" that might resemble his experience of losing a beloved offspring; Siti Lela passed away at the age of eight. "Thorny" relates to the symbol of a negative reaction among his friends and Islamic groups on anything that he did that contravened the conventions of the day. For example, he was referred to "pastor Abdullah" when he was actively involved in translation the Bible into Malay; he had a close relationship with the prominent Christian evangelists such as Pastor Thomson and Pastor Milne. Although Hadijah Rahmat's commentary is unclear on the issue of Abdullah's beliefs, her focus will always return to the axis of his written work that had existed and had been mentioned earlier as her truthful focus.

Observe too the lines "your touch still excites the taste/challenges the mind/opening pages of new spirits/changing the estuary of regional arts" and he was regarded as a poet only after two hundred years had passed. Abdullah was regarded as a prominent person of letters and allows room for assumptions, research and debate not only involving Malay studies in Malaysia and Singapore but also traversing the Malay Archipelago such as 
Indonesia and Brunei Darussalam.

In the coverage of her works in various genres, Hadijah Rahmat actively engages in cross genre works using Abdullah bin Abdul Kadir as her source that involves biography and articles that she produced. From the creative viewpoint, it spreads and transfers to the genres of theatre, telefilm, ${ }^{4}$ poems and soundtrack (songs). This leaning matches what Hadijah Rahmat herself confirms that it is her "academic and artistic" work that she unifies, especially seen in Munsyi.

Through this drama, in line with its title, Abdullah is given the title Munshi when he becomes the teacher or language master to the Benggala and Hindustan people (pp. 157-58). His command of the Malay language was such that he was able to teach and work with the English officers such as William Milne, Claudius Henry Thomas and Thomas Stamford Raffles. Hadijah Rahmat highlights the intellectual prowess of Abdullah in large part of this book, through his view on knowledge and skills.

For example, when two of Abdullah's friends, Salleh and Ali were fearful in their jobs with Pastor Milne and Pastor Thompson that required the reading of the Bible. However Abdullah's reaction was as follows:

\begin{abstract}
Based on my observation and interaction with them thus far, and also with other westerners, they are good people, educated and value knowledge and I respect their knowledge and friendship. I teach them and also learn from them. Knowledge is not easily acquired...ever since I was young, I had gone through difficulties to acquire knowledge. I shall continue to learn, nor matter from whom and from what source. The benefit of knowledge is to be given preference, and not to have unfounded suspicions. Both of you may not agree with my ways, but it does not matter. I will still continue with my way. I do not want be uneducated and live in ignorance and laziness like others. (pp. 80-81).
\end{abstract}

The same is shown when Abdullah was so regretful when he learned that Thomas Stamford Raffles's ship that carried Malay books caught fire (p. 130). Abdullah regarded this calamity as one in which the Malays had lost a valuable treasure and they could not read about the wonderful heritage.

In her creative works Hadijah Rahmat also gives focus to Abdullah similar to that in her academic works. Abdullah was the focus that fanned the spirit that was stated by Yatiman Yusof (in the feature in Munsyi).

Changing the mindset of the Malay society: (1) to raise and uphold the culture of knowledge; (2) to invite the Malay society to be critical towards all that they own and act accordingly; and (3) to open their minds to the 
outside world by learning foreign language and literature. This effort is expounded in all the works of Abdullah Munshi . The same objective is dug up, formulated and served by Hadijah Rahmat in her historical drama Munsyi; from the perspective of the "New Malay".

In the meantime, the despondency of Hadijah Rahmat was once recorded in an article, "Sastera dan Manusia Baru" (Literature and the New Malay) (1991:175-212) on the future of literature. It can also be associated with her poems or her dramas. Among other things, she perceives the position of the Malay literature of Singapore as:

1. Malay Literature is expanding too slowly and far from adequate to fill in the materials for local Malay literature

2. There is a lack of literary works of quality produced; in fact in evaluating the works produced most writers are still unable to attain a high quality in writing.

3. The current literary works are still unable to reflect the lifestyle and inner mind of the New Malay society, that are trying to improve their quality of life; but rather reflecting the disappointment and despair of the writers themselves who refuse to accept or are reluctant to accept the real fact of life in society today.

4. The writers do not place much attention to national issues that are connected to or affect the life of their society with that of the other societies in this country.

\section{CONCLUSION}

This paper expounds the special efforts of Hadijah Rahmat in highlighting the personae of Abdullah bin Abdul Kadir in her academic and creative works. In essence, Hadijah Rahmat stresses that the criticism laid by Abdullah on the Malays is with the objective of upgrading the status of his race. In using Abdullah's views, Hadijah Rahmat carries on the hope that the Malays can become a race that values knowledge, to open up their minds and learn new things, to have the intellectual courage to uplift their social standing in Singapore. As a learned Singapore Malay, Hadijah Rahmat chose the prominent Malay writer from across the sea, Abdullah bin Abdul Kadir as the focus that becomes the role model. The bilateral relationship not only becomes a symbol of a relationship between nations (Singapore and Malaysia) in literature, but also nurtures the Malay spirit that encompasses the region and the world. 
This paper shall conclude with the last three lines of all the poems that were written by Hadijah Rahmat in the series Kuliah Sastera Bandingan; (Lectures in Comparative Literature) in every country that she visited namely Malaysia, Indonesia and Brunei Darussalam. Perhaps it brings the heartfelt message to the regional Malays so as to become "a great race with a big heart"; a Malay who does not only improves his value but also creates a new value in a life that demands responsibility.

.

Sebuah bahtera seni

dioleng gelombang siasah

sebuah perahu sufi

masih terapung jauh

dari pusat

lautan makrifat

(A vessel of art

That rolls with the wave of politics

A boat deeply religious

Still floating far in the distance

From the center

of the sea of wisdom.)

Sebuah bahtera sastera

terdampar patah tiang haluan

sebuah perahu hayat

hilang syariat, terpinggir

dari lautan makrifat.

(A vessel of literature

Grounded with a broken rudder

A life bearing boat

Out of control and marginalized

From the sea of wisdom.)

(Jakarta 23 October 2001)

(Kuala Lumpur 18 October 2001)

Sebuah bahtera diraja

berkilauan dalam gelombang hakikat 
MALAY LITERATURE VOLUME 27 NUMBER 12014

sebuah perahu syariat

terapung sendirian di permukaan

Lautan makrifat

...

(A royal vessel

Shining in a wave of truth

A boat of rules

Floating alone on the surface

On the sea of wisdom)

(Brunei Darussalam, 27 October 2001)

\section{NOTES}

1 Chapter 1: The First Step: Tracing the Historical ....Over 200 Years; Chapter 2: The Historical Impressions in Melaka; Chapter 3: Impressions of Historical Traces in Singapore; Chapter 4: Impressions of Abdullah's Works in the Printing World; Chapter 5: Abdullah's Works Heritage; Chapter 6: Literary Heritage - The Concept of Authorship and Self in Hikayat Abdullah; Chapter 7: Talking Points in the Malay Academic Fraternity; Chapter 8: After the Surrender of Singapore; Chapter 9: The Voice of the New Generation; Chapter 10: Selected Dictions from Abdullah's Thoughts; Chapter 11: Closing Steps - Reliving History.

2 This Series of Lectures was started by Professor Dr. Sapardi Djoko Damono (1997), Professor Dr. Md. Salleh Yaapar (1998), Dr. Luisa J. Mallari-Hall (1999), Dr. Ampuan Haji Brahim bin Ampuan Haji Tengah (2000), Associate Professor Dr. Hadijah Rahmat (2001), Associate Professor Dr. Rattiya Salleh (2002), Emeritus Professor Dr. Budi Darma (2003), Professor Dr. Sahlan Mohd Saman (2004), Professor Dr. Ungku Maimunah Mohd Tahir (2008), Associate Professor Dr. Shaharuddin Maaruf (2006), Dr. Morsidi Muhamad (2011), Professor Dr. Ayu Sutarto (2011), Professor Dr. Sohaimi Abdul Aziz (2012), Dr. Azhar Ibrahim (2013)

3 In "Bahtera Seni" from Kurnia Alam, apart from the poem "Bahtera Seni" which refers to Abdullah's status and contribution, Hadijah Rahmat also wrote a poem about other reknown literary figures/artists like Jalal ad-Din Muhammad Rumi, S. Mohdir (Mohamed Abdul Kadir), Affandi, Faridu'd-Din Abu Hamid Muhammad Ibrahim, Arena Wati, Van Gogh and Masuri SN. On the whole all the poems were the poet's assumption in appreciating their works.

4 It was aired on Prime 12 on 5 October 1998 for two hours beginning 8:30 pm. The telefilm directed by Azizah Malik was played by Rashid Din (Abdullah), Idris Bakar (Farquhar), Zarul al Bakri (Raffles), Aziz Singah (Sultan Hussein Shah) and Osman Zailani (Temenggung Abdul Rahman) 


\section{REFERENCES}

Hadijah Rahmat, 1998a. Di Tengah Alam. Kuala Lumpur: Dewan Bahasa dan Pustaka. Hadijah Rahmat, 1998b. Munsyi: Drama Sejarah Sempena 200 Tahun Kelahiran Munsyi Abdullah bin Sheikh Abdul Kadir (1796-1854). Singapore: Teater Kami Limited.

Hadijah Rahmat, 1998c. Sastera dan Manusia Melayu Baru: Kumpulan Esei dan Wawancara. Kuala Lumpur: Dewan Bahasa dan Pustaka.

Hadijah Rahmat, 1999. Antara Dua Kota: Mengesan Jejak-jejak Peninggalan Munsyi Abdullah di Melaka dan Singapura. Singapore: Regional Training and Publishing Centre.

Hadijah Rahmat, 2001. In Search of Modernity: A Study of Concepts of Literature, Authorship and Notions of Self in Traditional of Malay Literature. Kuala Lumpur: Academy of Malay Studies, Universiti Malaya.

Hadijah Rahmat, 2005a. Kilat Senja: Sejarah Sosial dan Budaya Kampung-kampung di Singapura. Singapore: HSYang.

Hadijah Rahmat, 2005b. Mengukir Air di Pesisir Sastera Melayu/Indonesia dalam Arus Jagat. Kuala Lumpur: Dewan Bahasa dan Pustaka.

Hadijah Rahmat, 2006. Peranan dan Perkembangan Sastera Kanak-kanak. Kuala Lumpur: Dewan Bahasa dan Pustaka

Hadijah Rahmat, 2010a. Bunga Kasih Ibu. Singapore: HS Yang.

Hadijah Rahmat, 2010b. Burung Kenek-kenek. Singapore: HS Yang.

Hadijah Rahmat, 2013. Kurnia Alam. Singapore: HS Yang.

Syed Naguib al Attas, 1972. Islam dalam Sejarah dan Kebudayaan Melayu. Bangi: Universiti Kebangsaan Malaysia.

Ungku Maimunah Mohd Tahir, 1999. "Kerangka Konseptual "Kemodenan" Sastera Melayu: Satu Penilaian Kembali Tulisan Barat" dlm. Dewan Sastera hlm. 51-58, Disember 1999.

(Translated by Malim Ghozali PK) 


\section{Appendix}

\section{Brief Biodata of Associate Professor Dr. Hadijah Rahmat}

Professor Madya Dr. Hadijah Rahmat was born on 22 Februari 1958 in Kampung Haji Salam, Bedok, Singapura. She received her early education at Sekolah Melayu Siglap (1965-1967), Sekolah Rendah Bedok (1968-1970), Sekolah Menengah Maju (1971-1974) and Maktab Rendah Kebangsaan (1975-1976). She continued her education at Universiti Nasional Singapura (NUS) (1977-1979) until graduating with a Bachelor of Arts, Geografy and Malay Language). In 1980, she completed a Post Graduate Education Diploma Program at National Institute of Education Singapore (NIE) and continued her education at NUS, Masters of Arts (MA) in Malay Studies (1982-1984). From 1992-1995) Hadijah continued her education at doctorate level with Doctor of Philosophy at the School of Oriental and African Studies (SOAS), London University specialising in Indonesian and Malay Studies. She became a visiting Fulbright Scholar at University of California, Berkeley and Harvard University USA (Nov 2002-Mei 2003), Joint Fellow, International Institute of Asian Studies, IIAS, Leiden (September 2010-December 2010) and Visiting Professor at SOAS (January-March 2011). In 2011, she was chosen as the recipient of Tokoh Anugerah Tun Seri Lanang, Singapura.

Hadijah Rahmat started as a geografy teacher at the Changkat Secondary School, Changi (1986-1987). Apart from directly and formally involved NIE, she was also involved in various professional posts as Chairman of Kurikulum Bahasa Melayu dan Semakan Pedagogi (MLCPRC, 2005) di under the Education Ministry; Chairman, Steering Committee of Malay Language Syllabuses and Instructional Materials.

Hadijah Rahmat is active in social work, for example she was involved in the Committee of Malay Language Council (MICA) since 2001. She is the Deputy Works Council (Education), National Forum, Knowledge Based Economy for Malay Society (1999), Panel of Judges Berita Harian-MacDonald's Achiever of the Year (1999-2004), and Advisory Panel Member of Talent (TAP), People's Association of Singapore (2006) and Advisory Committee of National Library Board (from 2000). She represented Singapore as a panel judges for the Literary Prize MASTERA In 2001, she was chosen to lecture at the comparative literature forum at di Kuala Lumpur, Brunei and Jakarta.

She has been involved in the local development of arts and literature as specialist consultant to the National Arts Councils (since 1998), Committee in Dramatic Studies (1999-2002), Panel Judge for the Cultural Medallion Grant (2001), Editor for NAC Special Millennium Projects (Rhythms, 2000; Selves, 2002); Committee Member Censorship Review (2003), Advisory Committee of Programs, Singapore Broadcasting Authority (1995-1999), Deputy Chairman for Committee of Publication Appeal.

Her academic works and books include Peranan dan Perkembangan Sastera Kanak-kanak (Dewan Bahasa dan Pustaka, 2006), In Search of Modernity: A Study 
of Concepts of Literature, Authorship and Notions of Self in Traditional of Malay Literature (Akademi Pengajian Melayu, Universiti Malaya, 2001), Sastera dan Manusia Melayu Baru: Kumpulan Esei dan Wawancara (Malaysia Press, 1998c) and Kilat Senja: Sejarah Sosial dan Budaya Kampung-kampung di Singapura (HS Yang, 2005). Meanwhile her creative works include poems in the collections $D i$ Tengah Alam (Dewan Bahasa dan Pustaka, 1998), Kurnia Alam (HS Yang, 2013); including two books on children's poems, Bunga Kasih Ibu (HS Yang, 2010) and Burung Kenek-kenek (HS Yang, 2010).

Presently Associate Professor Dr. Hadijah Rahmat is the Head of Malay Language and Culture and Deputy Head, Asian Academic and Language Group, Nanyang University of Technology Singapore. 